\title{
EFEK INTERVENSI MINUMAN TEMPE TERHADAP TEKANAN DARAH PENDERITA HIPERTENSI DAN HIPERKOLESTEROLEMIA
}

\author{
(The effect of tempe drink intervention on blood pressure in hypertension and \\ hypercholesterolemia subjects)
}

\author{
Alfia Ansarullah ${ }^{1}$, Hardinsyah ${ }^{1}$, Sri Anna Marliyati ${ }^{1}$, Made Astawan ${ }^{2 *}$ \\ ${ }^{1}$ Departemen Gizi Masyarakat, Fakultas Ekologi Manusia (FEMA), Institut Pertanian Bogor, Bogor 16680 \\ ${ }^{2}$ Departemen Ilmu dan Teknologi Pangan, Fakultas Teknologi Pertanian, Institut Pertanian Bogor, \\ Bogor 16680
}

\begin{abstract}
The aim of this study was to determine the effect of tempe drink intervention on blood pressure of hypertension and also hypercholesterolemia subjects. This study used a Randomized Controlled Trial (RCT) design with 30 males and females subjects, who were divided into three treatment groups-tempe drink of A formulated from local sprouted soybean (TDA), tempe drink of B formulated from imported soybean (TDB), and control. The inclusion criterias were adults aged 25-55 years, not being menopause and pregnant, total cholesterol levels $\geq 200 \mathrm{mg} / \mathrm{dl}$, systolic blood pressure level 121-139 $\mathrm{mmHg}$, diastolic blood pressure level $81-89 \mathrm{mmHg}$ and willing to partcipate in research by signing an informed consent. The tempe drink was given three glasses a day for four weeks continuously, contained at least $25 \mathrm{~g}$ of protein/day. The control group was not given the tempe drink. Blood pressure data were collected every week during intervention. The results showed that the effect of TDA and TDB compared to control subjects on systolic blood pressure was significantly different. Other ways the effect of TDA and TDB compared to control subjects on diastolic blood pressure was not significantly different, but the trend was decreasing.
\end{abstract}

Keywords: blood pressure, hypertension, tempe drinks

\begin{abstract}
ABSTRAK
Tujuan penelitian ini adalah mengetahui efek intervensi minuman tempe terhadap tekanan darah pada penderita hipertensi dan sekaligus hiperkolesterolemia. Desain yang digunakan dalam penelitian ini adalah Randomized Controlled Trial (RCT) dengan total 30 subjek pria dan wanita yang dibagi dalam tiga kelompok, yaitu kelompok yang diberi Minuman Tempe A (MTA) yang diformulasikan dari keledai lokal yang dikecambahkan, Minuman Tempe B (MTB) yang diformulasikan dari kedelai impor, dan kelompok kontrol. Kriteria inklusi yaitu dewasa berusia 25-55 tahun, belum mengalami menopause atau tidak sedang hamil, kadar kolesterol total $\geq 200 \mathrm{mg} / \mathrm{dl}$, tekanan darah 121-139 $\mathrm{mmHg}$, tekanan darah diastolik 81-89 $\mathrm{mmHg}$ serta bersedia berpartisipasi dalam penelitian dan menandatangani informed consent. Minuman tempe diberikan tiga gelas sehari selama empat minggu berturut-turut dan paling sedikit mengandung $25 \mathrm{~g}$ protein/hari. Kelompok kontrol tidak diberi minuman tempe. Darah untuk analisis kadar kolesterol total dikumpulkan melalui darah vena setelah puasa sebelum dan setelah intervensi. Tekanan darah dikumpulkan setiap minggu selama intervensi. Hasil penelitian menunjukkan bahwa terdapat perbedaan signifikan pada efek MTA dan MTB dibandingkan dengan subjek kelompok kontrol pada tekanan darah sistolik. Tidak terdapat perbedaan signifikan pada efek MTA dan MTB pada tekanan darah diastolik dibandingkan dengan kelompok kontrol, namun kecenderungan mengalami penurunan.
\end{abstract}

Kata kunci: hipertensi, minuman tempe, tekanan darah

\footnotetext{
"Korespondensi: Telp: +628161374074, Surel: mastawan@yahoo.com
} 


\section{PENDAHULUAN}

Hipertensi merupakan penyakit yang biasa juga disebut silent disease karena seringkali tidak menimbulkan gejala, sementara tekanan darah yang terus menerus tinggi dalam jangka waktu yang lama dapat menimbulkan komplikasi dengan penyakit lainnya. Berdasarkan Riskesdas (2013), ditemukan bahwa prevalensi hipertensi mengalami penurunan dari $31,7 \%$ pada tahun 2007 menjadi $25,8 \%$ pada tahun 2013 untuk kelompok umur $\geq 18$ tahun. Umumnya penderita hipertensi adalah orang dengan usia diatas 40 tahun, namun saat ini hipertensi bisa saja diderita oleh kelompok usia yang lebih muda. Sebagian besar hipertensi primer terjadi pada usia 24-45 tahun dan hanya $20 \%$ terjadi dibawah usia 20 tahun dan diatas 50 tahun (Dhianingtyas \& Hendrati 2006). Hipertensi yang berlangsung lama dapat menjadi faktor risiko munculnya penyakit degeneratif lainnya, seperti stroke dan penyakit kardiovaskular (Kemenkes 2013). Semakin tinggi kadar kolesterol, maka lebih banyak terjadinya aterosklerosis dalam pembuluh darah, sehingga menyebabkan semakin tinggi resistensi vaskular sistemik dan memicu peningkatan tekanan darah (Desmond et al. 2005).

Peningkatan kadar Low Density Lipoprotein (LDL) menjadi faktor risiko utama aterosklerosis. Penyakit sirkulasi darah disebabkan oleh aterosklerosis yang diawali dengan terjadinya dislipidemia yaitu peningkatan kadar kolesterol total, LDL, trigliserida, maupun penurunan High Density Lipoprotein (HDL). Banyak faktor risiko yang memengaruhi timbulnya aterosklorosis, namun yang merupakan faktor risiko utama adalah peningkatan kadar kolesterol khususnya kolesterol LDL (Epstein \& Ross 1999). Meningkatnya kolesterol akan meningkatkan risiko hipertensi. Kadar kolesterol serum meningkat seiring dengan terjadinya peningkatan tekanan darah. Konsentrasi serum pada penderita hipertensi lebih tinggi daripada subjek normotensif yang mengindikasikan adanya risiko terkena komplikasi kardiovaskular yang lebih besar, seperti penyakit jantung koroner (PJK) dan stroke pada penderita hipertensi dengan kadar kolesterol yang tinggi (Akuyam et al. 2009).

Berbagai penelitian telah membuktikan bahwa pemberian kedelai dapat menurunkan hipertensi. Penelitian Welty et al. (2007) menunjukkan bahwa kedelai dapat menurunkan tekanan darah sistolik dan diastolik secara signifikan (Welty et al. 2007). Demikian halnya dengan penelitian yang dilakukan oleh Rivas (2002) yang menunjukkan bahwa pemberian $500 \mathrm{ml}$ susu kedelai selama tiga bulan mampu menurunkan tekanan darah sistolik dan diastolik. Studi Utari (2011) dengan pemberian tempe $160 \mathrm{~g} /$ hari selama 4 minggu pada wanita menopause dapat menurunkan kadar LDL, trigliserida, dan kolesterol total.

Tempe merupakan makanan fermentasi populer Indonesia. Pengolahan tempe menjadi minuman tempe serbuk siap seduh bersifat inovatif dan lebih praktis, mudah dikonsumsi dan lebih tahan lama. Pesatnya pengembangan tempe menjadi pangan fungsional yang dapat menurunkan tekanan darah menjadi alasan peneliti untuk melakukan penelitian mengenai efek dari minuman berbasis tempe terhadap tekanan darah pada penderita hipertensi dan hiperkolesterolemia. Penelitian ini bertujuan untuk mengkaji kadar tekanan darah sistolik dan diastolik sebelum dan setelah intervensi minuman tempe.

\section{METODE}

\section{Desain,tempat, dan waktu}

Penelitian ini menggunakan desain Randomized Controlled Trial (RCT). Penelitian terdiri atas tiga kelompok yaitu 1) kelompok yang mendapatkan intervensi minuman tempe A, 2) kelompok yang mendapatkan minuman tempe B, dan 3) kelompok kontrol yang tidak mendapatkan intervensi minuman tempe. Minuman tempe A dibuat menggunakan tempe kedelai Grobogan (lokal) yang dikecambahkan, sedangkan minuman tempe B dibuat menggunakan tempe kedelai Genetically Modified Organisms (GMO) impor yang tidak dikecambahkan. Pembagian subjek ke dalam masing-masing kelompok dilakukan secara acak (random assignment).Keseluruhan kegiatan penelitian mulai dari persiapan hingga pengolahan dan analisis data dilaksanakan pada bulan Maret hingga Oktober 2015. Intervensi dilaksanakan selama empat minggu pada bulan Mei hingga Juni 2015 di IPB, Dramaga. Pemeriksaan profil lipid dilakukan di Laboratorium Kesehatan Daerah (Labkesda) Bogor.

\section{Jumlah dan cara pengambilan subjek}

Penentuan jumlah subjek penelitian ini mengacu pada rumus Lemeshow (1997) sebagai berikut.

$$
\mathrm{n}=\left(2 \sigma^{2}\left(Z_{1-\alpha}+Z_{1-\beta}\right)^{2}\right) /(\mu 1-\mu 2)^{2}
$$


Berdasarkan hasil penelitian yang dilakukan Utari (2011), pengaruh pemberian intervensi tempe terhadap kadar kolesterol dan LDL dewasa usia 40-64 tahun, dengan mengambil salah jenis pertama (tingkat kesalahan) $\alpha=0,05$, dan power test sebesar 1- $\beta=0,90, \sigma=16,7$ (standar deviasi kolesterol LDL), perubahan kolesterol LDL (mg/ dl) perlakuan kontrol adalah meningkat $(\mu 2)=$ 14,1 dan intervensi tempe menurun $(\mu 1)=-7,8$, kemudian disubstitusikan ke dalam rumus diatas, maka diperoleh jumlah subjek minimum 10 sampel per kelompok. Populasi penelitian adalah tenaga kependidikan IPB yang dikumpulkan melalui pemberian surat ke divisi masing-masing untuk menghadiri skrining.

Subjek yang terpilih merupakan subjek yang telah memenuhi kriteria inklusi meliputi pria dan wanita berusia 25-55 tahun, wanita yang belum mengalami menopause atau tidak sedang hamil, tekanan darah sistolik $\geq 121 \mathrm{mmHg}$, tekanan darah diastolik $\geq 81 \mathrm{mmHg}$, kadar kolesterol total $\geq 200 \mathrm{mg} / \mathrm{dl}$, serta bersedia berpartisipasi dalam penelitian dengan menandatangani persetujuan informed consent. Adapun kriteria eksklusi subjek yaitu bila berpartisipasi dalam penelitian lain, tidak menyukai kedelai atau tempe, mengonsumsi obat penurun tekanan darah dan kolesterol. Selama pelaksanaan intervensi, asupan makanan subjek tidak batasi baik konsumsi tempe maupun makanan lainnya.

Protokol pelaksanaan penelitian telah mendapatkan persetujuan etik dari komite etik penelitian kesehatan FK UI Nomor: 282/UN2. F1/ETIK/2015.

\section{Tahapan penelitian}

Formulasi dan intervensi minuman

tempe. Pembuatan minuman tempe menggunakan bahan baku tempe yang diproduksi oleh RTI (Rumah Tempe Indonesia), sedangkan seluruh produk minuman tempe diproduksi oleh PT. Harapan Bunda Mandiri. Produk tersebut telah mendapatkan sertifikat halal oleh MUI dengan No. 01121087880513 dan sertifikat Dinkes P-IRT dengan No.515327102017118. Produk minuman tempe diberikan dalam bentuk serbuk minuman tempe siap seduh yang dikemas dalam kemasan plastik. Produk minuman tempe dibuat dengan menambahkan tepung terigu, garam, gula, minyak nabati, dan baking powder dengan tiga variasi rasa (cokelat, vanila, dan pisang). Minuman tempe disiapkan sendiri oleh subjek sesuai dengan prosedur yang telah ditentukan.

Minuman tempe A menggunakan kedelai Grobogan (lokal) dikecambahkan untuk me- nyaingi kadar protein minuman tempe $\mathrm{B}$ yang menggunakan kedelai impor GMO yang tidak dikecambahkan (Sirait 2015). Prosedur pengecambahan kedelai mengacu pada penelitian Ichsan (2015), prosedur pembuatan tempe mengacu pada proses pembuatan tempe komersial di Rumah Tempe Indonesia (RTI) dan diadopsi oleh Ichsan (2015), selanjutnya prosedur pembuatan produk minuman tempe berbentuk serbuk siap seduh mengacu pada penelitian Mahmud (1987) dengan beberapa modifikasi oleh Sirait (2015). Hasil penelitian Astawan et al. (2013) menyatakan bahwa tempe yang dibuat menggunakan kedelai varietas Grobogan dan tempe yang dibuat dari kedelai impor GMO tidak memiliki perbedaan yang signifikan $(p<0,05)$, baik dari segi rendemen, kadar protein, sifat fisik, dan organoleptik secara keseluruhan. Tepung tempe juga memiliki mutu gizi yang lebih baik dibandingkan tepung kedelai rebus, bahkan lebih baik jika dibandingkan kasein (Astawan et al. 2015). Konsumsi tempe Grobogan tidak berpengaruh terhadap organ tubuh terutama pada hati, ginjal, dan testis tikus percobaan yang menunjukkan bahwa konsumsi tempe ini tidak berdampak negatif terhadap kesehatan (Astawan et al. 2015b).

Intervensi. Produk dikonsumsi oleh subjek sebanyak tiga bungkus per hari masing-masing seberat $35 \mathrm{~g}$ per bungkus, maka total produk yang seharusnya dikonsumsi selama 4 minggu intervensi adalah 84 bungkus kelompok A memperoleh produk yang dikemas dalam plastik tertutup dan diberi label A atau B pada kardusnya untuk memudahkan pada saat pembagian produk ke subjek, sedangkan kelompok kontrol tidak memperoleh produk intervensi. Produk minuman tempe dibagikan dua kali dalam seminggu selama empat minggu intervensi, yaitu setiap hari senin dan kamis. Minuman tempe tersebut disiapkan sendiri oleh subjek sebelum diminum. Pada awal kegiatan intervensi, kepada seluruh subjek diberikan edukasi gizi mengenai gizi seimbang.

\section{Jenis dan cara pengumpulan data}

Data yang dikumpulkan dalam penelitian ini terdiri atas data karakteristik subjek (meliputi jenis kelamin, umur, tingkat pendidikan, dan status merokok) yang diperoleh melalui wawancara dan pengisian kuesioner pada awal penelitian (data baseline). Data status gizi (berat dan tinggi badan) dikumpulkan melalui pengukuran menggunakan timbangan berat badan digital dan $m i-$ crotoice sebanyak dua kali (sebelum dan setelah intervensi). 
Data kolesterol total, pengambilan sampel darah pada sebelum dan setelah intervensi dilakukan pada pagi hari (jam 08.00-10.00). Subjek diminta untuk tidak makan dan minum (kecuali air putih) sejak jam 22.00 sebelum pengambilan darah dilakukan di pagi hari. Sampel darah darah diambil sebanyak $6 \mathrm{cc}$ melalui pembuluh vena yang diambil oleh tenaga kesehatan terlatih dari Labkesda, kemudian dianalisis di laboratorium menggunakan metode spektrofotometri dan data tekanan darah diperoleh melalui pengukuran menggunakan spygmomanometer sebanyak lima kali (saat baseline dan satu kali dalam seminggu). Data kepatuhan subjek juga dikumpulkan dua kali per minggu (hari senin dan kamis) melalui wawancara dan pengisian kuesioner kepatuhan serta pengembalian bungkusan produk. Jika subjek tidak patuh (kepatuhan $\leq 70 \%$ ) mengonsumsi minuman tempe maka akan di drop out.

\section{Pengolahan dan analisis data}

Data tekanan darah sistolik dan diastolik subjek sebelum dan setelah intervensi dianalisis menggunakan paired-sampels $T$ test, sedangkan untuk delta (nilai perubahan/selisihnya) dianalisis menggunakan uji one way Anova. Setelah itu, dilakukan uji lanjut Duncan antar kelompok untuk mengetahui kelompok yang secara signifikan berbeda dengan kelompok lainnya. Uji Analysis of Covariance (Ancova) dilakukan untuk mengetahui efek intervensi minuman tempe terhadap tekanan darah sistolik dan diastolik dengan memasukkan kovariat. Ancova dilakukan untuk meningkatkan presisi hasil penelitian karena didalamnya dilakukan pengaturan terhadap pengaruh peubah bebas lain atau confounder yang tidak terkontrol.

\section{HASIL DAN PEMBAHASAN}

\section{Karakteristik subjek}

Tabel 1 menunjukkan karakteristik umum subjek yang meliputi jenis kelamin, umur, pendidikan, status gizi, dan status merokok. Hasil uji Kruskal wallis pada Tabel 1 menunjukkan bahwa karakteristik subjek antar kelompok tidak berbeda secara signifikan sehingga perubahan hasil intervensi dianggap merupakan pengaruh dari intervensi bukan karakteristik subjek.

Total subjek yang terpilih berjumlah 30 orang. Subjek terbanyak yaitu perempuan berjumlah 53,3\%, dengan persentase terbesar berada di kelompok B. Data Riskesdas (2013) menunjukkan bahwa prevalensi hipertensi berdasarkan jenis kelamin, lebih tinggi pada perempuan daripada laki-laki (Kemenkes 2013). Jenis kelamin memiliki peran penting pada hipertensi yang berkaitan dengan berat badan dan konsentrasi kolesterol (Coylewright et al. 2008). Penelitian Yang et al. (2015) menunjukkan bahwa prevalensi hipertensi pada perempuan akan meningkat seiring dengan meningkatnya usia.

Rata-rata umur subjek adalah 44 tahun, dengan persentasi subjek terbesar di kelompok umur 25-45 tahun yang merupakan kelompok umur dengan risiko relatif rendah, namun seiring

Tabel 1. Sebaran subjek berdasarkan karakteristik

\begin{tabular}{|c|c|c|c|c|c|c|c|c|c|}
\hline \multirow{3}{*}{ Variabel } & \multicolumn{6}{|c|}{ Kelompok } & \multirow{2}{*}{\multicolumn{2}{|c|}{ Total $(n=30)$}} & \multirow{3}{*}{$\mathrm{p}$} \\
\hline & \multicolumn{2}{|c|}{$\begin{array}{c}\mathrm{A} \\
(\mathrm{n}=10)\end{array}$} & \multicolumn{2}{|c|}{$\begin{array}{c}\mathrm{B} \\
(\mathrm{n}=10)\end{array}$} & \multicolumn{2}{|c|}{$\begin{array}{c}\text { Kontrol } \\
(\mathrm{n}=10)\end{array}$} & & & \\
\hline & $\mathrm{n}$ & $\%$ & $\mathrm{n}$ & $\%$ & $\mathrm{n}$ & $\%$ & $\mathrm{n}$ & $\%$ & \\
\hline \multicolumn{10}{|l|}{ Jenis kelamin } \\
\hline Laki-laki & 6 & 60,0 & 3 & 30,0 & 5 & 50,0 & 14 & 46,7 & \multirow{2}{*}{0,404} \\
\hline Perempuan & 4 & 40,0 & 7 & 70,0 & 5 & 50,0 & 16 & 53,3 & \\
\hline \multicolumn{10}{|l|}{ Umur } \\
\hline 25-45 tahun & 7 & 70,0 & 6 & 60,0 & 4 & 40,0 & 17 & 56,7 & \\
\hline $46-55$ tahun & 3 & 30,0 & 4 & 40,0 & 6 & 60,0 & 13 & 43,3 & \\
\hline Rata-rata \pm SD & \multicolumn{2}{|c|}{$42,4 \pm 8,0$} & \multicolumn{2}{|c|}{$42,5 \pm 6,9$} & \multicolumn{2}{|c|}{$44,8 \pm 8,9$} & \multicolumn{2}{|c|}{$43,2 \pm 7,8$} & 0,399 \\
\hline \multicolumn{10}{|l|}{ Pendidikan } \\
\hline SD & 0 & 0,0 & 0 & 0,0 & 1 & 10,0 & 1 & 3,3 & \multirow{5}{*}{0,492} \\
\hline SMP & 1 & 10,0 & 1 & 10,0 & 0 & 0,0 & 2 & 6,7 & \\
\hline SMA & 5 & 50,0 & 2 & 20,0 & 2 & 20,0 & 9 & 30,0 & \\
\hline Diploma & 1 & 10,0 & 2 & 20,0 & 2 & 20,0 & 5 & 16,7 & \\
\hline Perguruan tinggi & 3 & 30,0 & 5 & 50,0 & 5 & 50,0 & 13 & 43,3 & \\
\hline \multicolumn{10}{|l|}{ Status merokok } \\
\hline Merokok & 2 & 20,0 & 0 & 0,0 & 2 & 20,0 & 4 & 13,3 & \multirow{2}{*}{0,328} \\
\hline Tidak merokok & 8 & 80,0 & 10 & 100,0 & 8 & 80,0 & 26 & 86,7 & \\
\hline \multicolumn{10}{|l|}{ Status gizi } \\
\hline Normal & 4 & 40,0 & 3 & 30,0 & 4 & 40,0 & 11 & 36,7 & \\
\hline Overweight & 0 & 0,0 & 2 & 20,0 & 1 & 10,0 & 3 & 10,0 & \\
\hline Obesitas & 6 & 60,0 & 5 & 50,0 & 5 & 50,0 & 16 & 53,3 & \\
\hline Rata-rata $\pm \mathrm{SD}$ & \multicolumn{2}{|c|}{$29,2 \pm 8,0$} & \multicolumn{2}{|c|}{$26,7 \pm 2,2$} & \multicolumn{2}{|c|}{$26,1 \pm 4,0$} & \multicolumn{2}{|c|}{$27,4 \pm 5,3$} & 0.962 \\
\hline
\end{tabular}


dengan pertambahan umur, maka semakin besar risiko hipertensi (Chataut 2011; Wei 2015). Bertambahnya usia akan memengaruhi perubahan fisiologis yang terjadi pada tubuh antara lain perubahan jumlah, susunan, dan struktural dari sel endotel, peningkatan produksi spesies oksigen dan terjadi inflamasi (Kumar et al. 2014). Semua perubahan yang terjadi merupakan faktor risiko untuk meningkatkan tekanan darah (Mateos et al. 2011).

Lebih dari separuh subjek berpendidikan tinggi, sepertiga subjek berpendidikan menengah dan hanya satu orang yang lulus SD. Sebagian besar subjek (86,7\%) tidak merokok. Komponenkomponen pada rokok dapat merusak dinding pembuluh darah, dan meningkatkan pembentukan platelet pada dinding yang dapat mengurangi elastisitas pembuluh darah yang menyebabkan kekakuan sehingga tekanan darah meningkat (Salahuddin et al. 2012).

Lebih dari separuh subjek $(53,3 \%)$ memiliki status gizi yang termasuk dalam kategori obes. Prevalensi obesitas yang ditemukan pada penelitian ini lebih tinggi dari angka nasional berdasarkan Riskesdas (2013) sebesar 15,4\%. Status gizi overweight dan obes dapat meningkatkan tekanan darah melalui mekanisme penyempitan pembuluh darah akibat penumpukan lemak dalam tubuh (Rahmouni 2005).

\section{Tekanan darah}

Tabel 2 menunjukkan bahwa hasil paired $T$ test tekanan darah sistolik secara signifikan menurun pada kelompok A dan B antara sebelum dan setelah intervensi, tetapi pada kelompok kontrol tidak berbeda secara signifikan. Berbeda halnya dengan tekanan darah diastolik, yang menun- jukkan bahwa terjadi penurunan yang signifikan pada kelompok A (minuman tempe A) dibandingkan dengan kelompok kontrol.

Hasil Anova pada Tabel 2 menunjukkan bahwa intervensi minuman tempe berpengaruh signifikan terhadap tekanan darah sistolik. Tekanan darah sistolik pada kelompok A dan B berbeda signifikan dengan kelompok kontrol. Hasil Anova menunjukkan bahwa tidak ada perbedaan signifikan terhadap tekanan darah diastolik pada kelompok A dan B tidak berbeda signifikan dibandingkan dengan kelompok kontrol.

Hasil Ancova untuk tekanan darah sistolik menunjukkan hasil yang tidak signifikan namun ada kecenderungan nilai tersebut menurun. Hal ini disebabkan karena dalam penelitian ini, intervensi yang dilakukan dipengaruhi oleh confounder yaitu umur dan tekanan darah sistolik baseline.

Hipertensi merupakan masalah yang kompleks, berkaitan dengan usia, jenis kelamin, obesitas sentral, konsumsi alkohol dan genetik (Adrogue \& Madias 2007). Tekanan darah sistolik baseline juga berpengaruh terhadap intervensi yang dilakukan karena memiliki nilai yang sangat bervariasi, mulai dari $121 \mathrm{mmHg}$ sampai $156 \mathrm{mmHg}$. Sama halnya dengan tekanan darah sistolik, uji Ancova juga menunjukkan hasil yang tidak signifikan pada tekanan darah diastoli. Hal ini berarti intervensi yang dilakukan tidak berpengaruh terhadap tekanan darah diastolik. Tekanan darah diastolik juga dipengaruhi oleh confounder tekanan darah baseline pada saat intervensi.

Berdasarkan penelitian oleh Kholifah (2013), pemberian susu tempe tidak berpengaruh signifikan terhadap tekanan darah. Dalam pene-

Tabel 2. Tekanan darah sistolik dan diastolik subjek menurut kelompok, sebelum dan setelah intervensi

\begin{tabular}{|c|c|c|c|c|c|}
\hline \multirow{2}{*}{ Variabel } & \multicolumn{3}{|c|}{ Kelompok } & \multirow{2}{*}{$\mathrm{p}^{1)}$} & \multirow{2}{*}{$\mathrm{p}^{2)}$} \\
\hline & A & $\mathrm{B}$ & Kontrol & & \\
\hline \multicolumn{6}{|c|}{ Tekanan darah sistolik (mmHg) } \\
\hline Sebelum & $136,6 \pm 10,9^{a, 1}$ & $135,2 \pm 8,3^{\mathrm{a}, 1}$ & $127,9 \pm 8,4^{\mathrm{a}, 1}$ & 0,10 & \multirow{4}{*}{0,06} \\
\hline Setelah & $126,5 \pm 6,8^{\mathrm{a}, 2}$ & $125,2 \pm 6,0^{\mathrm{a}, 2}$ & $127,5 \pm 9,7^{\mathrm{a}, 1}$ & 0,79 & \\
\hline $\mathrm{p}^{3)}$ & $0,00^{*}$ & $0,00^{*}$ & 0,81 & & \\
\hline Delta (perubahan) & $-10,1 \pm 6,4^{\mathrm{a}}$ & $-10,0 \pm 6,9^{a}$ & $-0,4 \pm 5,1^{\mathrm{b}}$ & $0,00^{*}$ & \\
\hline \multicolumn{6}{|c|}{ Tekanan darah diastolik (mmHg) } \\
\hline Sebelum & $85,1 \pm 7,7^{\mathrm{a}, 1}$ & $82,4 \pm 8,9^{\mathrm{a}, 1}$ & $77,4 \pm 7,3^{\mathrm{a}, 1}$ & 0,11 & \multirow{4}{*}{0,26} \\
\hline Setelah & $78,7 \pm 4,6^{\mathrm{a}, 2}$ & $81,4 \pm 7,1^{\mathrm{a}, 1}$ & $76,4 \pm 4,9^{\mathrm{a}, 1}$ & 0,16 & \\
\hline $\mathrm{p}^{3)}$ & $0,00^{*}$ & 0,65 & 0,62 & & \\
\hline Delta (perubahan) & $-6,4 \pm 5,8^{\mathrm{a}}$ & $-1,0 \pm 6,8^{\mathrm{a}}$ & $-1,0 \pm 6,2^{a}$ & 0,10 & \\
\hline
\end{tabular}

Keterangan: Data disajikan dalam bentuk rata-rata \pm standar deviasi; *signifikan $\mathrm{p} \leq 0,05$; a,b huruf yang sama pada baris yang sama menunjukkan tidak ada pengaruh/ perbedaan signifikan $\mathrm{p}>0,05 ;{ }^{1,2}$ angka yang sama pada kolom yang sama menunjukkan tidak ada pengaruh/ perbedaan signifikan $\mathrm{p}>0,05 ; \mathrm{p}^{1)}$ Anova antara kelompok A, B, dan kontrol; $\mathrm{p}^{2)}$ Ancova antara kelompok A, B, dan kontrol; $\mathrm{p}^{3)}$ Paired-samples $T$ test antara sebelum dan setelah intervensi. 
litian ini, peneliti melakukan intervensi selama satu bulan pada wanita pralansia dan lansia dengan rentang usia 45-70 tahun. Jika dibandingkan dengan penelitian ini, maka hasil yang tidak signifikan tersebut diduga karena rentang waktu penelitian yang kurang lama, sehingga intervensi tempe yang diberikan tidak berpengaruh secara signifikan tetapi cenderung menurunkan tekanan darah jika dibandingkan dengan kelompok kontrol. Berbagai penelitian menggunakan kedelai dengan rentang waktu yang lebih lama (lebih dari 4 minggu) menunjukkan terjadinya penurunan tekanan darah sistolik dan diastolik (Rivas 2002; Welty 2007; He 2011).

Penurunan tekanan darah sistolik yang terjadi diduga karena adanya protein kedelai yang mengandung asam amino arginin yang merupakan prekursor untuk nitric oxide (NO) yang memiliki efek vasodilator. Nitric oxide memiliki sifat menghambat agregasi (penggumpalan) platelet darah sehingga dapat melancarkan sirkulasi darah (Harrison 2000). Kedelai mengandung isoflavon yang merupakan fitoestrogen yang secara struktural mirip dengan estrogen yang diduga menunjukkan aktivitas antihipertensi melalui peningkatan NO dan menurunkan angiotensin serta mampu menghentikan reaksi pembentukan radikal bebas. Dalam kedelai terdapat tiga jenis isoflavon, yaitu daidzein, glisitein, dan genistein (Nakajima et al. 2005; Yang 2005; Astawan 2013). Beberapa penelitian menunjukkan kedelai memiliki efek positif terhadap tekanan darah pada penderita hipertensi (Harrison 2000; Sagara 2004; Yang 2005).

Tempe memiliki beberapa kelebihan dibandingkan dengan kedelai yaitu memiliki daya cerna protein, karbohidrat, dan lemak yang lebih baik, kandungan vitamin yang lebih tinggi, serta bioavailibilitas mineral yang lebih baik. Perlakuan perkecanbahan yang dilakukan dapat meningkatkan kadar protein (Astawan 2016b). Proses fermentasi oleh $R$. oligosporus yang terjadi pada proses pengolahan kedelai menjadi tempe mampu menghidrolisis protein dan beberapa senyawa kompleks lainnya menjadi bentuk yang lebih sederhana seperti asam amino dan peptidapeptida (Astawan et al. 2016). Tempe yang bersifat hipotensive juga disebabkan oleh adanya peptida bioaktif tempe yang mampu bersifat sebagai inhibitor ACE (Angiotensin Converting Enzyme). ACE adalah enzim yang mengubah angiotensin I menjadi angiotensin II. Angiotensin inilah yang memiliki peranan kunci dalam menaikkan tekanan darah. Tempe yang diproduksi dengan menggunakan laru pasar (inokulum campuran) memiliki aktivitas penghambatan ACE lebih besar $\left(\mathrm{IC}_{50}\right.$ lebih kecil) dibandingkan dengan tempe yang diproduksi dengan menggunakan inokulum murni (Astawan et al. 2016).

Kepatuhan subjek selama intervensi berlangsung dihitung berdasarkan jumlah bungkusan produk yang diminum dalam seminggu. Rata-rata kepatuhan subjek digolongkan tinggi dengan persentase $>80 \%$ pada masing-masing kelompok intervensi.

\section{KESIMPULAN}

Intervensi minuman tempe dari kedelai Grobogan (lokal) yang dikecambahkan (A) dan minuman tempe dari kedelai GMO impor yang tidak dikecambahkan (B) sebanyak tiga gelas/ hari selama empat minggu pada subjek prahipertensi dan hiperkolesterolemia menunjukkan terdapat perbedaan signifikan efek intervensi minuman tempe dari kedelai Grobogan (lokal) yang dikecambahkan (A) dan minuman tempe dari kedelai GMO impor yang tidak dikecambahkan (B) dibandingkan dengan kelompok kontrol pada tekanan darah sistolik, namun tidak ada perbedaan signifikan pada tekanan darah diastolik dibandingkan dengan kelompok kontrol, namun terdapat kecenderungan mengalami penurunan.

Penelitian ini telah menunjukkan bahwa pemberian minuman tempe pada penderita hipertensi dan hiperkolesterolemia belum mampu menurunkan tekanan darah (sistolik dan diastolik). Saran untuk penelitian selanjutnya adalah sebaiknya lama/durasi pemberian intervensi terkhusus pada penderita hipertensi lebih lama dari penelitian ini.

\section{UCAPAN TERIMA KASIH}

Peneliti mengucapkan terima kasih kepada pemberi dana penelitian, yaitu Direktorat Riset dan Pengabdian Masyarakat, Direktorat Jenderal Penguatan Riset dan Pengembangan, Kementerian Riset, Teknologi dan dan Pendidikan Tinggi, melalui skema "Hibah Kompetensi 2015-2017" atas nama Made Astawan.

\section{DAFTAR PUSTAKA}

Adrogue HJ, Madias NE. 2007. Sodium and potassium in the pathogenesis of hypertension. N Engl J Med 356(19):1966-1978. 
Akuyam S, Aghogho, U, Aliyu, I, Bakari, A. 2009. Serum total cholesterol in hypertensive Northern Nigerians. Int $\mathrm{J}$ Med Med Sci 1(3):73-78.

Astawan M, Hermanianto J, Suliantari, Sugiyanto GSP. 2016. Application of vacuum packaging to extend the shelf life of fresh-seasoned tempe. Int Food Res J 23(6):2571-2580.

Astawan M, Wresdiyati T, Ichsan M. 2016b. Karakteristik fisikokimia tepung tempe kecambah kedelai. J Gizi Pangan 11(1):3542.

Astawan M, Wresdiyati T, Widowati S, Bintari SH, Ichsani N. 2013. Karakter fisikokimia dan sifat fungsional tempe yang dihasilkan dari berbagai varietas kedelai. J Pangan 22(3):209-286.

Astawan M, Wresdiyati T, Saragih AM. 2015. Evaluasi mutu protein tepung tempe dan tepung kedelai rebus pada tikus percobaan. Jurnal Mutu Pangan 2(1):11-17.

Astawan M, Wresdiyati T, Sirait J. 2015b. Pengaruh konsumsi tempe kedelai grobogan terhadap profil serum, hematologi dan antioksidan tikus. J Teknol dan Industri Pangan 26(2):155-162.

Chataut J, Adhikari RK, Sinha NP. 2011. Prevalence and risk factors for hypertension in adults living in central development region of Nepal. Univ Med J 33(1):13-18.

Coylewright M, Reckelhoff JF, Ouyang P. 2008. Menopause and hypertension an age-old debate. J Hypertens 51(4):952-959.

Desmond G, Julian J, Campbell C, James M, McLenachan. 2005. Cardiology. Elsevier Saunder.

Dhianingtyas Y, Hendrati LY. 2006. Risiko obesitas, kebiasaan merokok, dan konsumsi garam terhadap kejadian hipertensi pada usia produktif. The Indonesian Journal of Public Health 1(1):105-109.

Epstein FH, Ross R. 1999. Atherosclerosisan inflammatory disease. N Engl J Med 340(2):115-126.

Harrison BLM, Raij L. 2000. Postmenopausal hypertension. Current hypertension reports 2(2):202-207.

He J, Wofford MR, Reynolds K, Chen J, Chen CS, Myers L, Minor DL, Elmer PJ, Jones DW, Whelton PK. 2011. Effect of dietary supplementation on blood pressure a randomized, controlled trial. Circulation 124:589-595. doi: 10.1161/CIRCULATIONAHA.110.009159.
Ichsan M. 2015. Perbandingan karakteristik fisikokimia tempe dengan tempe kecambah kedelai [skripsi]. Bogor: Institut Pertanian Bogor.

[Kemenkes] Kementerian Kesehatan. 2013. Riset Kesehatan Dasar 2013. Jakarta: Balitbangkes Kementerian Kesehatan RI.

Kholifah HN. 2013. Pengaruh pemberian susu tempe terhadap tekanan darah pra lansia dan lansia di posyandu lansia dusun Brajan Tamantirto Kasihan Bantul Yogyakarta : Universitas Muhammadiyah Yogyakarta.

Kumar V, Abbas AK, Fausto N, Aster JC. 2014. Robbins and cotran pathologic basis of disease, Professional Edition: Expert ConsultOnline. Elsevier Health Sciences.

Mahmud MK. 1987. Penggunaan makanan bayi formula tempe dalam diit bayi dan anak balita sebagai suatu upaya penanggulangan masalah diare [disertasi]. Bogor: Institut Pertanian Bogor.

Mateos CPJ, Zamorano-León JJ, Rodríguez-Sierra P, Macaya C, LópezFarré AJ. 2011. New and old mechanisms associated with hypertension in the elderly. Int J Hypertens.

Nakajima N, Nozaki N, Ishihara K, Ishikawa A, Tsuji H. 2005. Analysis of isoflavone content in tempeh, a fermented soybean, and preparation of a new isoflavone-enriched tempeh. J Biosci Bioeng 100(6):685-687.

Rahmouni K, Correia ML, Haynes WG, Mark AL. 2005. Obesity-associated hypertension new insights into mechanisms. J Hypertens 45(1):9-14.

Rivas M, Garay RP, Escanero JF, Cia P, Alda JO. 2002. Soy milk lowers blood pressure in men and women with mild to moderate essential hypertension. J Nutr 132(7):19001902.

Sagara M, Kanda T, NJelekera M, Teramoto T, Armitage L, Birt N, Yamori Y. 2004. Effects of dietary intake of soy protein and isoflavones on cardiovascular disease risk factors in high risk, middle-aged men in Scotland. J Am Coll Nutr 23(1):85-91.

Salahuddin S, Prabhakaran D, Roy A. 2012. Pathophysiological mechanisms of tobacco-related CVD. Glob Heart 7(2):113-120.

Sirait YIS. 2015. Karakterisasi serbuk minuman berbasis tempe [skripsi]. Bogor: Institut Pertanian Bogor.

Utari DM. 2011. Efek Intervensi Tempe Terhadap Profil Lipid, Superoksida Dismutase, LDL Teroksidasi dan Malonaldehyde Pada 
Ansarullah dkk.

Wanita Menopause [disertasi]. Bogor: Institut Pertanian Bogor.

Wei Q, Sun J, Huang J, Zhou HY, Ding YM, Tao YC, He SM, Liu YL, Niu JQ. 2015. Prevalence of hypertension and associated risk factors in Dehui city of Jilin province in China. J Hum Hypertens 29(1):64-68.
Yang G, Ma Y, Wang S, Su Y, Rao W, Fu Y, Yu Y, Kou C. 2015. Prevalence and correlates of prehypertension and hypertension among adults in northeastern China: A cross-sectional study. Int J Environ Res Publ Health 13(1):82.

Yang G, Shu XO, Jin F, Zhang X, Li HL, Li Q, Zheng W. 2005. Longitudinal study of soy food intake and blood pressure among middle-aged and elderly Chinese women. Am J Clin Nutr 81(5):1012-1017. 